\title{
A Review on Recent Developments on Propagating Mango (Mangifera indica L.) through Grafting
}

\author{
Mude Arun Kumar Naik ${ }^{*}$ and Nangunuri Varun Kumar
} Department of Horticulture, School of Agriculture, Lovely Professional University,
Phagwara, Punjab, India

*Corresponding author

\section{A B S T R A C T}

\section{Keywords}

Mango, Grafting, survival, Seasons, Type of grafting

Article Info

Accepted:

24 October 2020

Available Online:

10 November 2020

\begin{abstract}
Mango is propagated by both sexual and vegetative propagation. Various methods of propagation include softwood, veneer grafting, side grafting, and epicotyl grafting, which are most commonly found in India. Factors such as environmental factors, varieties, growing seasons, shoot age, rootstock age, scion wrapping technique, shoot maturity and rootstock, etc. all of these have an impact on the success and survivability of mango grafting. When compared to a season of the year, rainy season transplant in mango shows good growth and survival percentage results. Most common grafting are inarching, side grafting, wedge grafting, and veneer grafting, but the cheap, easy and fast grafting was stone grafting, which they produce in a shorter time and area in good quantity and quality. This method is widely used in the states of Karnataka, Maharashtra, and Kerala. The months of July - August, September - October shows the higher grafting success. Grafting can only be carried out between closely related species. The biggest advantage of grafting is that it changes the properties of the plant and makes it superior to its mother plant.
\end{abstract}

\section{Introduction}

Mangifera indica L. (Mango) is the most important fruit crop in all of India and belongs to the Anacardiaceae family. It is the national fruit of India known as the king of fruits. (National Mango Data Base 2020) Origin is in South Asia, particularly North East India, Burma, and the Andaman Islands, mangoes have long been raised, admired, and respected in their hometowns. Buddhist monks are believed to have made mangoes in Asia Minor and East Asia in the fourth and fifth centuries BC. The Persians are said to have been brought to East Africa in the Tenth century AD. It is usually cultivated in the East Indies before the first visit of the Portuguese, who are believed to have introduced it to West Africa and Brazil in the early 16th century. After settling in Brazil, mangoes were transported to the West Indies, planted around Barbados around 1742, and later in the Dominican Republic. It reached Jamaica around 1782 and reached Mexico from the Philippines and the West Indies in the early Nineteenth century National Mango Data Base 2020). It is associated with many traditional religious and traditional practices 
of the time (Chattopadhyay et al., 1976). It was cultivated in India over 4 centuries ago. All categories of fruits such as unripe, ripe, and ripe, are used for their nutritional value and delicious taste. Young and unripe fruits are sour and are used to make chutney and pickles. Ripe fruits are widespread and are used to make several products such as gels, jams, toffees, nectar, squashes, juice, baby food etc. In Java and the Philippines, the mango leaves are used for cooking purposes (Munde, 2011).

Mango trees are cultivated in both tropical and subtropical areas. Moderate rains favor the growth from June to October. Rain causes delayed flowering during the pre-flowering and flowering period and improves the vegetative growth of the fruit. The flowering time of mango trees is induced by the temperature level of the climatic conditions. Mango is produced worldwide, especially in countries like Israel, Thailand, Egypt, the Philippines, Indonesia, Southeast Africa, tropical Australia, Burma, Sri Lanka, and the USA (Yadav, 2016). In most areas, mango is grown, while the leading states in area and production in India are Uttar Pradesh, Madhya Pradesh, Bihar, and Andhra Pradesh. Gujarat, Karnataka, Tamil Nadu, Orissa, West Bengal, Maharashtra, Madhya Pradesh, Kerala, and Punjab are also states where mango production occurs. Districts of Andhra Pradesh, like Chittoor, Krishna, and Anantapur are very famous in mango production and also produce lots of varieties.

Mango is propagated by seeds or by vegetative techniques. Even as the propagation of seed is the easiest way, this process needs to be avoided since the crosspollinated crop does not produce true progenies. The need for an honest method of propagation should aim to produce planting material of a uniform and true type. Among the various methods of asexual propagation, grafting may be a critical physiological process with different developmental stages, affected by environmental factors, rootstock age, grafting method, and cultivar used.

The mango was mainly propagated by stones in ancient years/times, but today various grafting techniques are developed and used in mango cultivation. Grafting is a method where parts of plants are joined together, and grow as a single plant. The upper portion is the scion that grows on another plant's root system (rock stock). Grafting can only be carried out between closely related species. The biggest advantage of grafting is that it changes the properties of the plant and makes it superior to its mother plant. Another is that, as compared to a sexual method of propagation, it increases production by providing fruits in a short time. It offers nonuniform bearing and fruits are inferior only in situations where the plant is grown from seed. Grafting also plays a significant role in developing inferior varieties. It's a popular and preferred propagation method (Bally 2006). Compatibility is the principal factor of grafting. If both the rootstock and the scion are compatible with each other, the latest shoot will begin to grow. Based on the desirable characters, the rootstock is selected.

\section{Effect of variety}

(Bobade et al., 2018) Maximum growth parameter values such as sprout height (6.02 $\mathrm{cm})$, shoot length $(27.97 \mathrm{~cm})$, secondary root length $(23.73 \mathrm{~cm})$ have also been recorded in grafts of the variety Mallika and Kesar grafts were closely followed. Karim reported that Sindhu (80.12 percent) was the largest success, followed by the Fazli and the Hybrid 10 (73.05 percent) and (68.32 percent) and the Gopalbhog of (55.25 percent) was the lowest. A higher sprouting success of $(65 \%$ - 90\%) was recorded by Dashehari. The average leaf number is (8.27) and 6-month survival 
$(65.35 \%)$ than the Langra in a July Singh et al., were noted. Radha et al., (1999) Observed that plant heights ranged from $26.3 \mathrm{cms}$ in Chandrakaran to $36.5 \mathrm{cms}$ in Bangalora in 6 months.

\section{Scion characteristics}

(Singh and Srivastava 1979) had done several studies on variables affecting mango veneer grafting success. They suggested that Scions aged 6 months and grafted in rootstocks aged 2 years in July and August obtained the best results. The bud sticks had been defoliated and kept for 3-5 days in moss wrapped with polythene before grafting. Polythene strips gave the best results of the many tying materials. It was reported by Majumder et al., that the grafting experiment between August and November on wedge and splice grafting was carried out. Splice grafting has achieved up to $80.00 \%$ success but poor survival.

(Iqbal et al., 1982) has recorded the vegetative mango propagation in Fiji. He found that the grafting of the side wedge and cleft was the most efficient way of providing mango grafts using a 5 - $6 \mathrm{~mm}$ wide scion on the rootstock of the same diameter. He also saw that the grafting was more successful (50 - 95\%) than the grafting in exposed conditions under $50 \%$ shade.

\section{Rootstock attributes}

(Geetha et al., 1997). Noted that in Muvandan and Chandrakaran grafted with cv. Neelam Grafting's success was highest (96.67 percent) during June and survival in Puliyan grafted with cv. Banganapally was highest (76.67 percent) during August. In January, The grafted seedlings were planted at the age of 18 to 24 months results showed that in both grafting combinations, rootstock Carabao survived all temperatures
(Islam et al., 2004) reported that the highest percentages of survival $(56.82 \%$ and 52.98 $\%$ ) were obtained by scions of Gopalbhog and Amrapali On May 16, mangoes were grafted onto two-year-old rootstock. Scion and rootstock survival and growth were examined 120 days after grafting with grafting on 15 April, The most pronounced growth of the rootstock was $(44.57 \mathrm{~cm})$. Higher survival (66.13 percent) for Amrapali was reported among the cultivars.

\section{Season of grafting}

(Sabeky et al., 2005) performed a trial to decide the best period and process for mango grafting and stated that the highest level of effective grafting was reached on April 4 is $(67.2 \%)$ with grafting. After 90 days, side and softwood grafts achieved higher success rates $(65.8 \%)$ and $(63.7 \%)$ respectively $(47.5 \%)$ than shield budding. After 180 days the proportion of gown scions and scion lengths of these grafted was (55 percent) and $57.9 \mathrm{~cm}$, respectively, and these values improved to (65.6 percent) and $60.6 \mathrm{~cm}$ after that period".

(Prasanth et al., 2007) conducted a research evaluation to study which variety takes less time by using Mallika, Baneshan, and Khader to see softwood grafting in the mango. Early sprouting (24.50 days) is performed at various times during grafting was observed by September grafting.

In the fortnight of September grafting, a significant the highest percentage of sprouting and grafting take (82.50) was reported (54.56 percent). Low sprouting regarding sprouting and graft survival was observed during grafting in December. Mallika displayed the very best percentage of sprouting among the three cultivars (68.90 percent)and then (Khalil) Noted that the best time was found between May and September for grafting. 
(Dhaandar DG et al., 1985) recorded (92 percent) success during the July season with veneer grafting. Patil et al., observed at Dharwad, Karnataka. When a stone grafting is carried out with on7 to 10-day old seedling as rootstock during the $1^{\text {st }}$ week of July, Mulgoa mango gave 100 percent successful grafting while Alphonso, Pairi and Totapari, showed (40 percent), (53.33 percent) and (53.33 percent) successful grafting, respectively. From (Patil AA et al., 1991) In June, grafting recorded the highest average length, and in August after 180 days recorded the highest survival under grafting.

"During the months of July-August, September and October, (Jacob et al., 2001) announced the greater success of the graft (90 percent). On August $16^{\text {th }}$, Pandey and Singh recorded the highest scion sprout (76.33 percent) and subsequent survival (40.22 percent) of the stone graphed Mango cv Amrapali in Varanasi. Prasanth et al., examined mango cotyledon grafting and reported that grafting resulted in early sprouting (28.71 days) and late sprouting (35.10 days) in the Northeastern dry zone of Karnataka in the first quarter of August."

The time of grafting in mango had high significant influence on the percent of successful grafts. Ismail and Rao (1988) pointed out that the grafting mango from January to December gave the best result and produced a higher percentage of grafting success. Thus, the key reasons for increasing the percentage of effective grafting are mild temperature and high relative humidity (Ram, 1997) (Table 1 and 2).

Table.1 Source: All India Area, Production and Productivity of Mango in India

\begin{tabular}{|c|c|c|c|c|c|}
\hline Year & $\begin{array}{c}\text { Area Of } \\
\text { Mango } \\
\text { (ha) }\end{array}$ & $\begin{array}{c}\text { Total } \\
\text { Percentage } \\
\text { Of Fruiting } \\
\text { Area }\end{array}$ & $\begin{array}{c}\text { Production } \\
\text { (MT) }\end{array}$ & $\begin{array}{c}\text { Total } \\
\text { Percentage } \\
\text { Of Fruit } \\
\text { Production }\end{array}$ & $\begin{array}{c}\text { Productivity } \\
\text { MT/ha }\end{array}$ \\
\hline $\mathbf{2 0 1 4}-\mathbf{2 0 1 5}$ & 2163.5 & 35.41 & 18527 & 21.39 & 8.5 \\
\hline $\mathbf{2 0 1 5}-\mathbf{2 0 1 6}$ & 2208.6 & 35.05 & 18642.5 & 20.67 & 8.4 \\
\hline $\mathbf{2 0 1 6}-\mathbf{2 0 1 7}$ & 2262.8 & 34.92 & 19686.9 & 21.20 & 8.7 \\
\hline
\end{tabular}

(National Mango Data Base)

Statistics Source: National Mango DataBase

Table.2 Shows the success rate percentage of mango propagation

\begin{tabular}{|l|l|l|l|}
\hline Type of Propagation & Month & Success rate\% & Reference \\
\hline Stone Grafting & August & $40.22 \%$ & (Pandey and Singh 1992) \\
\hline Shield Budding & July & $47.05 \%$ & (Sabeky et al., 2005) \\
\hline Softwood Grafting & September & $54.56 \%$ & (Prasanth et al., 2007) \\
\hline Softwood Grafting & July & $63.07 \%$ & (Sabeky et al., 2005) \\
\hline Side Grafting & July & $65.08 \%$ & (Sabeky et al., 2005) \\
\hline Splice Grafting & August and November & $80.00 \%$ & (Majumder et al., 1969) \\
\hline Softwood Grafting & July & $84.00 \%$ & (Singh and Srivastava 1980) \\
\hline Softwood Grafting & August & $87.00 \%$ & (Singh and Suryanarayana 1996) \\
\hline Stone Grafting & July & $92.00 \%$ & (Dhaandar DG et al., 1985) \\
\hline
\end{tabular}




\section{Graft success percentage}

Singh and Srivastava (1980) conducted softwood grafting research in July, which reported the highest performance (84 percent). For 2 years, they were used from July to September and from March to April to study softwood grafting. In August, a 90\% success rate followed by July (64.85 percent) was reported. From June to October in Andaman, Then studied mango softwood grafting and achieved the highest grafting performance (87\%) during August.

From (Prasad et al., 1990) by taking Banganapally, The final observation was that the precured scions (78.96 percent) were more competitive than the non-precured scions (52.75 percent). A study of various aspects of mango veneer grafting was carried out (1990). With 100 day old scions it was good at $71.08 \%$ and with 120-day old scions, the lowest was $62.67 \%$. With precured scions, the mean survival of graft after potting was $75.39 \%$ and $52.28 \%$ with non-precured scions, which is often, happens after grafting as material grafted within the nursery is grown and potted.

A research study was done by (Nayak and Sen 2000) and concluded that In January, when grafting was carried out, (55 days) the time taken to bud split was greater compared to July-August (26 days. Even as was performed in July-August, the amount of success was higher (78.8 percent) compared with the (75 percent) from January to March. In winter grafted plants, however, the overall development rate was higher. Jana reported that in Tommy Atkins and Amrapali, the maximum leaf number was observed. Many detached grafting methods have been successfully used in recent times as an important rapid and economic method of mango propagation.

\section{Success percentage for graft combination}

Gurudutta et al., (2012) studies the grafted on Kurukkan rootstock with various cultivars of scions such as Amrapali, Dashehari, Mallika, and Langra at Raipur, Chhattisgarh conditions. In the Dashehari variety, followed by Langra, the most successful percentage (93.33 percent) was recorded. The percentage of grafting on local rootstock of twelve varieties of mango was assessed by (Jadhav et al., 2014). The maximum percentage of success (95 percent) was recorded in the mango Totapuri cultivar.

Kumar and Thakur (2016) researched the mango stones used as scion for growing seedling rootstocks and the Dashehari variety scion used for separate unknown commercial cultivars. Concerning survival, sprouting and overall success of stone grafts over other growing mixtures, the growing medium used in the composition of the soil + sawdust was found to be the simplest growing mixture. The survival of mango grafting obtained when grafting made with scion sticks are preserved on the cutting side with wax coating and wrapping in the moist cotton and stored at room temperature for 3 days was studied by (Thakur and Shah 2013).

Singh et al., (2014) the upper survival percentages were examined by 5-day and 10day-old rootstock, suggesting suitability for this method. When 10-day-old rootstock was used for grafting, stone or epicotyl grafting was found to do well for survival and growth.

In conclusion the recent times mainly for commercial purpose traditional propagating types are less practiced due to their short survival rate and using the popularizing new ways like Grafting to overcome and tolerate the conditions of salt stress, many soil-borne Pathogens and diseases, mainly invasion of nematodes into roots later causing complete 
wilting of the whole plant which is a considerable and chief economical loss to the farmer. So after studying various practices by researchers and their noted records, it tells that the high relative humidity and the moderate temperature are the main factors for increasing the percent of success grafting. The best time for grafting was between May September. Varieties like Langra, Dashehari, Amrapali, and Mallika were the best scion for graft combination. In nursery mango seedling softwood grafting is great for graft success than other grafting methods. Store at room temperature for 3 days scion wrapped with moist cotton and wax coating at cutting position shows good results.

\section{References}

Alam, M. A., Islam, M. S., Uddin, M. Z., Barman, J. C., and Quamruzzaman, A. K. M. (2006). Effect of age of seedling and variety of scion in stone grafting of mango. Int. J. Sustain. Crop. Prod, 2, 27-32.

Bally, I. S. (2006). Mangifera indica (mango). Species profiles for pacific island agroforestry, 1-25.

Bobade, D. H., Ingole, R. H., and Kadam, A. S. (2018). Effect of Different Scio $n$ Varieties of Mango on Growth and Biomass Production per Formanc e of Stone Grafts (Mangifera indica L.). Int $J$ Curr Microbiol App Sc i Special Issue-6 pp, 1642-1648.

Chattopadhyay, N. C., and Nandi, B. (1976). Peroxidase and polyphenol oxidase activity in malformed mango inflorescence caused byFusarium moniliforme var. subglutinans. Biologia Plantarum, 18(5), 321-326.

Dhaandar DG (1985) Study on propagation of cashew nut with wedge grafting. Journal of Plantation crops 108: 285-286.

Geetha, T. K., Valsalakumari, P. K., Geetha, C. K., and Rajeevan, P. K. (1997). Influence of polyembryonic rootstocks on the success and survival of soft wood grafts on mango. Journal of Applied Horticulture Navsari, 3(1/2), 85-88.

Iqbal, M. (1982). A review of mango research and production in Fiji. Fiji Agricultural Journal, 44(1), 21-26.

Islam, M. N., Rahim, M. A., and Farooque, A. M. (2004). Standardization of time and grafting techniques in mango under Bangladesh condition. Asian Journal of Plant Sciences (Pakistan).

Ismail, S., and Rao, S. N. (1989). Studies on propagation time and method of operation for mango cv.Banganapally. Acta Horticulturae (Netherlands).

Jacob, S., Ray, D. P., Sahu, G. S., and Chandra, A. (2001). Studies on the success of soft wood grafting in some commercial hybrid mango (Mangifera indica L.). Orissa J. Hort, 29(2), 6-9.

Jana, B. R. (2007). Response of different mango cultivars to top-veneer grafting. JOURNAL OF RESEARCHBIRSA AGRICULTURAL UNIVERSITY, 19(1), 91.

Karim, R., Rahim, M. A., and Alam, M. S. (2004). Effect of leaf and node retention in rootstock on epicotyle grafting in mango. M. Sc.(Ag.) thesis, Hort. Dept. $B A U$, Mymensingh, 30-53.

Kumar, P., and Kathakur, N. (2016). Effect of age of rootstocks and different growing media on the success of stone grafting in mango, Mangifera indica L. International Journal of Farm Sciences, 6(1), 255-261.

Majumder, P. K., Mukherjee, S. K., and Rathore, D. S. (1969, June). Further researches on propagation techniques in mango. In Symposium on Mango and Mango Culture 24 (pp. 72-76).

Munde, G. R., Hingole, D. G., and Jahagirdar, J. E. (2011). Effect of single and double rootstock on grafting success in mango. International Journal of Plant Protection, 4(2), 330-332.

National Mango Data Base. (2020, November 11). Retrieved November 11, 2020, from ICAR National Mango Database: 
https://mangifera.res.in/indianstatus.php

Nayak, G., and Sen, S. K. (2000). Seasonal influence of veneer grafting of mango (Mangifera indica L.). Environment and Ecology, 18(1), 156-158.

Patil, A. A., Vadigeri, B. G., and Nalawadi, U. G. (1991). Response of mango varieties to stone grafting. Current Research, 20(7), 135-136.

Pawar, P. P., Bhosale, S. S., Gavali, A. V., and Yadav, D. B. (2016). World Mango Trade and Opportunities for India. Indian Journal of Agricultural Economics, 71(3), 310.

Prasad, P. V., Suryanarayana, V., and Naram, N. (1990). Studies on certain aspects of veneer grafting in mango (Mangifera indica L.) cv. Banganapally. South Indian Horticulture, 38(1), 1-7.

Prasanth, J. M., Reddy, P. N., Pampanagouda, B., and Patil, S. R. (2006). Effect of cultivars and time of grafting on percent success and survival of grafts in epicotyl grafting in Mango (Mangifera indica L.) in north-eastern dry zone of karnataka. Internat. J. Agric. Sci, 2(1), 1-3.

Prasanth, J. M., Reddy, P. N., Patil, S. R., and Pampanagouda, B. (2007). Effect of cultivars and time of softwood grafting on graft success and survival in mango. Agricultural Science Digest, 27(1), 1821.

Radha, T., and Aravindakshan, K. (1999, April). Differential response of mango varieties to epicotyl grafting on commercial scale. In VI International Symposium on Mango 509 (pp. 265268).

Sabeky, E. (2005). Study and Determination of the Best Time and Method for Mango Grafting in Bahokalate, Sistan Balouchestan Province. Journal of Science and Technology of Agriculture and Natural Resources.

Sing, A. R., Pandy, S. P., Sing, R. K., and Sing, N. D. (1992). Influence of cultivar and period of operation on the success of veneer grafting in mango. Adv. Hort. Forestry, 19(2), 17-23.

Singh DB, Suryanarayana MA (1996) Studies on softwood grafting in mango. Flora and Fauna 21: 83-84.

Singh, K. K., Chauhan, J. S., and Rawat, J. M. S. (2018). A Review: Vegetative Propagation of Mango (Mangifera indica L.) through Grafting. JOJ Hortic Arboric, 2(2), 555583.

Singh, N. P. (1980). A new approach towards double grafting in mango. Current Sci.,49 (17): 678-679

Singh, N. P., and Srivastava, R. P. (1979). Studies on the different aspects involved in veneer grafting in mango. Progressive horticulture.

Singh, N., Tripathy, S. M., and Ghumare, V. (2014). Studies on growth and survival of stone grafts as influenced by age of seedling rootstock in mango (Mangifera indica L.) cv. Amrapali. Journal of Applied and Natural Science, 6(2), 716719.

\section{How to cite this article:}

Mude Arun Kumar Naik and Nangunuri Varun Kumar. 2020. A Review on Recent Developments on Propagating Mango (Mangifera indica L.) through Grafting. Int.J.Curr.Microbiol.App.Sci. 9(11): 3481-3487. doi: https://doi.org/10.20546/ijcmas.2020.911.415 